\title{
PEMILIHAN MODA TRANSPORTASI SETELAH ADANYA KERETA COMUTER LINE (STUDI DAERAH PENYANGGA JAKARTA)
}

\author{
Aris Munandar \\ Dosen Jurusan Geografi FIS UNJ \\ Email : nandariz@yahooo.co.id
}

\begin{abstract}
This study aimed to get a general idea about the selection of transportation modes resident in the buffer after the comuter line. The research time of the month from May to July 2014. The population in this study were all passengers in the Depok, Bekasi , Tangerang stasiun. The sampling technique was done by purposive sampling, passengers who choose rail transportation mode before applying commuterline using other modes. Each station 30 so that the total of 90 respondents. Characteristic of the youngest respondents aged 16 years and the oldest 50 years with an average of 26.9 years. The Based work on non-civil . Based on the level of respondents at most high school education. Based on user characteristics of respondents have either two-wheel motor vehicles and driving licence (SIM) equipped. Motor vehicles used by the respondent as a feeder. Average of the marital status of unmarried respondents. For those who are married earned income respondents said inadequate needs . Inadequate income would find it difficult to save. Respondents largely did not participate in the community commuter line. Based on the characteristics of the movement of the majority of respondents travel destinations for work purposes .

Based on the characteristics mode facility, respondents to travel departing in the morning, come home in the afternoon rush hour. Respondents went on a trip with other existing modes. Respondents do not make the shift from the other trains. Travel time required respondents to make every trip is in accordance with her wishes. For short trips ( 10 stasion ) takes 50 minutes. Resonden not rest / sleep when the train. The cost for short trips ( 10 stations ) of Rp 3,000, including low cost. Respondents were more likely to use multi- trip cards than single trip. The respondents were unable to seat.
\end{abstract}

Keywords : comuter line, election, mode, transportation

\section{PENDAHULUAN}

Seperti di negara sedang berkembang lainnya, berbagai kota besar di Indonesia berada dalam tahap pertumbuhan urbanisasi yang tinggi akibat laju pertumbuhan ekonomi yang pesat sehingga kebutuhan penduduk untuk melakukan pergerakan menjadi semakin meningkat. Urbanisasi berbagai negara merupakan dampak teknologi transportasi modern pada interaksi desa-kota dan pada pola perluasan daerah inti yang berkembang pesat di berbagai Negara Asia.

Jumlah penduduk yang tinggal di daerah perkotaan di Indonesia diperkirakan meningkat dari tahun ketahun akibat tingginya urbanisasi. Sebagai gambaran dapat dilihat pada tabel dibawah ini :

\section{Tabel 1 Penduduk Indonesia yang Tinggal Di Perkotaan}

\begin{tabular}{lll}
\hline No & Tahun & Persentase \\
\hline 1. & 1920 & 5,8 \\
2. & 1980 & 17,0 \\
3. & 1990 & 25,4 \\
4. & 2025 & 59,5 \\
\hline
\end{tabular}

Sumber : Tamin 1997,353 
Tabel tersebut memperlihatkan jumlah penduduk Indonesia yang tinggal didaerah perkotaan. Terlihat bahwa pada akhir tahun 2025 sekitar 59,5\% orang akan tinggal diperkotaan. Jika kita menganggap penduduk Indonesia pada tahun 2025 sebanyak 240 juta orang, maka akan menjadi 144 juta penduduk Indonesia tinggal di daerah perkotaan.

Tantangan bagi pemerintah negara sedang berkembang, dalam hal ini instansi dan departemen terkait serta perencanaan transportasi perkotaan adalah pelayanan angkutan umum. Permasalahan transportai perkotaan pada umumnya berkembang sejalan dengan pertumbuhan penduduk, kenaikan pendapatan masyarakat, ketersedian kendaraan bermotor dan peningkatan aktivitas ekonomi maupun sosial.

Disisi lain perkembangan transportasi dengan semakin kompleks, baik di dalam kota maupun luar kota, kalau semula yang mencangkup pusat-pusat kegiatan baru hanya pada jalan-jalan utama, pada masa kini peningkatan jalan-jalan baru telah menarik berdirinya pusat-pusat perkembangan baru. Bentuk kota yang tidak kompleks dan terarah sejalan dengan berkembangnya jalan kota pula. Proses desentralisasi pemukiman penduduk maupun fungsi-fungsi perkotaan berajalan terus menerus dan semakin meningkatnya frekuensi serta volumenya (Yunus, 2000: 156).
Selain hal tersebut terdapat keterbatasan infrastruktur serta kurang siapnya pemerintah dengan strategi pengelolaan dan pranata kelembagaan. Berkembangnya industri dan kegiatan ekonomi membawa akibat makin berkembangnya pergerakan barang antar kota maupun dalam kota. Kondisi ini bersama meningkatnya intensitas angkutan penumpang menyebabkan pelayanan trnasportasi diperkotaan manjadi menurun.

Jakarta sebagai Ibukota Negara Republik Indonesia, pusat pemerintah, menyandang atribut kota metropolitan. Jakarta telah menjadi tempat yang menarik penduduk daerah-daerah lain yang dengan berbagai kepentingan, alasan dan bertempat tinggal. Perkembangan penduduk yang cepat tersebut tentu saja harus diikuti dengan meningkatkan aktivitas mereka diberbagai bidang dan juga akan menimbulkan masalah yang kompleks di Jakarta. Masalah tersebut menyangkut antara lain kebutuhan sarana dan prasarana transportasi, seperti kebutuhan akan jasa angkutan umum.

Kebutuhan jasa angkuatan umum sebagian dapat dipenuhi oleh kendaraan bermotor miliki pribadi, namun jumlah penduduk yang memiliki kendaraaan tersebut relatif sedikit. Oleh karena itu sebagian besar penduduk Jakarta akan bergantung pada jasa angkutan umum didalam kegiatannya sehari-hari seperti ke kantor, ke sekolah dan jasa kegiatan lainnya.

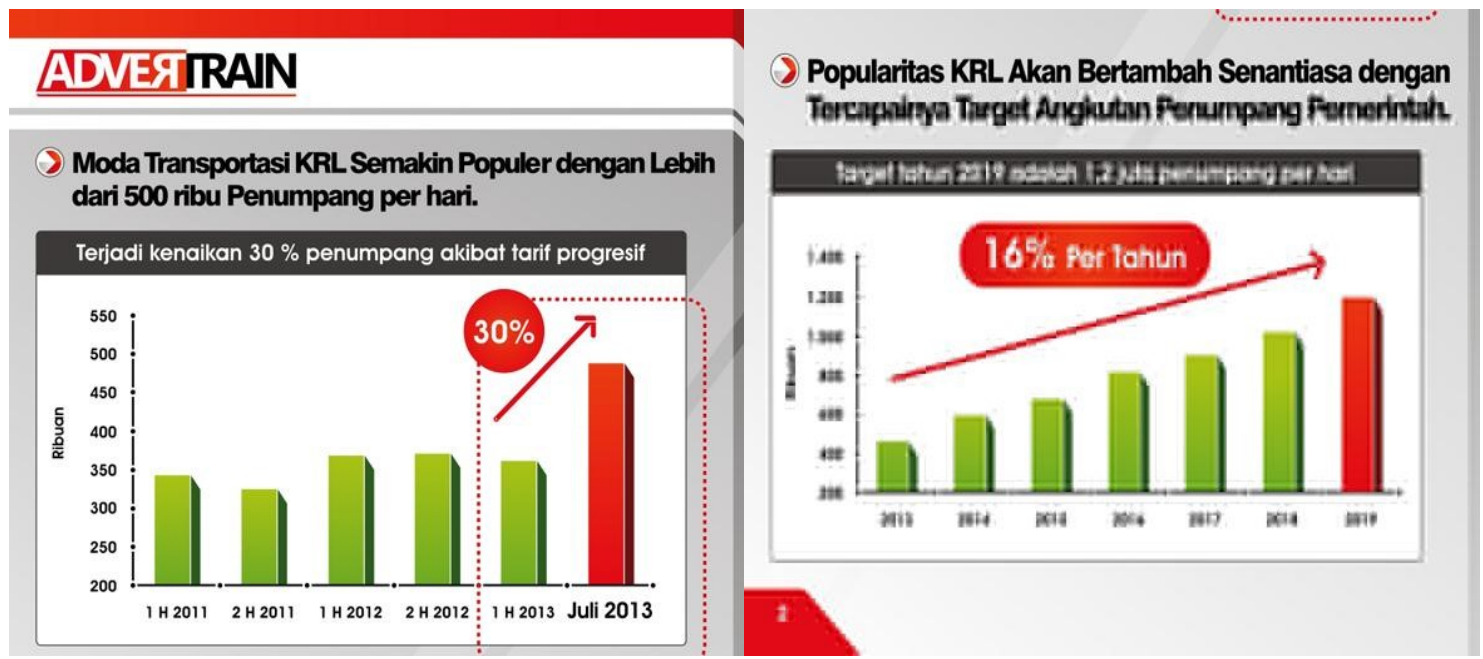

Grafik 1 Peningkatan penumpang KRL

SPATIAL Wahana Komunikasi dan Informasi Geografi Vol. 13 No. 1 Maret 2015 
Grafik menunjukan kenaikan penumpang kereta apai $16 \%$ pertahun. Dengan demikian kereta api menjadi moda pilihan bagi masyarakat yang tinggal didaerah penyangga Jakarta untuk melakukan aktivitas. Kereta api dianggap memiliki ketepatan dan kecepatan dalam pergerakan dibanding dengan kendaraan umum atau pun pribadi.

Kementerian

Perhubungan menganggarkan Rp1,22 triliun sebagai dana kewajiban pelayanan publik (public service obligation) untuk kereta api sepanjang tahun ini. Jumlah dana itu sebagian besar diserap Kereta Rel Listrik (KRL). Menurut data Kementerian Perhubungan, pada 2014 pemerintah menganggarkan dana PSO untuk kereta api sebesar Rp1,22 triliun. Jumlah PSO ini terdiri dari PSO Kereta Api (KA) ekonomi jarak jauh Rp167,91 miliar, KA ekonomi jarak sedang Rp94,5 miliar, KA ekonomi jarak dekat Rp284,15 miliar, KRD (kereta diesel) ekonomi sebesar Rp29,78 miliar, KRL Rp 641,45 miliar, dan KA ekonomi Lebaran sebanyak Rp6,44 miliar.

Rinciannya untuk KRL Jabodetabek adalah 13 relasi, 561 frekuensi perjalanan per hari, dan 300,282 juta pengguna jasa per tahun

Dengan berlakunya tiket komuter line yang cukup terjangkau, masyarakat memiliki keluasaan dalam pemilihan moda kereta api. Penggunaan moda yang berbasis jalan raya semakin hari semakin macet, sehingga masyarakat menggunakan moda kereta api untuk melakukan perjalanannya. Dalam penelitian ini masalah perumusan masalahnya yaitu bagaimana pemilihan moda transportasi penduduk di sekitar penyangga Jakarta setelah adanya kereta comuterline

\section{METODOLOGI PENELITIAN}

Penelitian ini bertujuan untuk mendapatkan gambaran umum tentang pemilihan moda transportasi penduduk di penyangga Jakarta setelah adanya kereta api Comuter line

Penelitian ini dilakukan di Stasiun -stasiun penyangga Jakarta yaitu Depok Bekasi dan
Tangerang dan waktunya dari Bulan Mei-Juli 2014. Populasi dalam penelitian ini adalah seluruh penumpang yang ada di Stasiunstasiun Depok, Bekasi, Tangerang. Teknik pengambilan sampel dilakukan dengan cara Purposive sampling, yaitu calon penumpang yang memilih moda transportasi kereta api yang sebelum berlaku kereta Comuter line menggunakan moda lain. Masing stasiun 30 orang Secara acidental sehingga total keseluruhan 90 responden. Metode yang digunakan dalam penelitian ini adalah deskriptif dengan pendekatan survey. Data diperoleh melalui data sekunder dan data primer. Data primer melalui interview/wawancara terstruktur dengan berpedoman pada instrumen penelitian. Data hasil lapangan kemudian di tabulasikan kemudian dengan persentase untuk melihat kecenderungan jawaban dari responden. Kemudian dianalisis berdasarkan hasil data sekunder dan primer.

\section{HASIL DAN PEMBAHASAN}

Pemilihan moda transportasi sangat beragam tergantung dari banyak faktor. Beberapa faktor yang mempengaruhi pemilihan moda yaitu ciri pengguna jalan, ciri pergerakan dan ciri fasiilitas moda. Ciri pengguna jalan, seperti ketersediaan atau kepemilikan kendaraan pribadi, kepemilikan Surat Izin Mengemudi, struktur rumah tangga, pendapatan dan faktor lain. Ciri pergerakan, sangat dipengaruhi: tujuan pergerakan, waktu terjadi pergerakan, jarak perjalanan. Ciri fasilitas moda transportasi meliputi : waktu perjalanan, biaya transportasi, ketersediaan ruang.

Identitas responden yang dijaring dalam penelitian ini meliputi umur, pekerjaan dan tingkat pendidikan. Berdasarkan umur paling muda 16 tahun dan paling tua 50 tahun dengan rata-rata 26,9 tahun. Umur yang paling dominan antara 20-30 tahun yang menggunakan moda transportasi comuterline. Golongan umur ini paling dominan karena komuterline terutama di jam sibuk terjadi kepadatan yang mengakibatkan kekurangan nyamanan. 


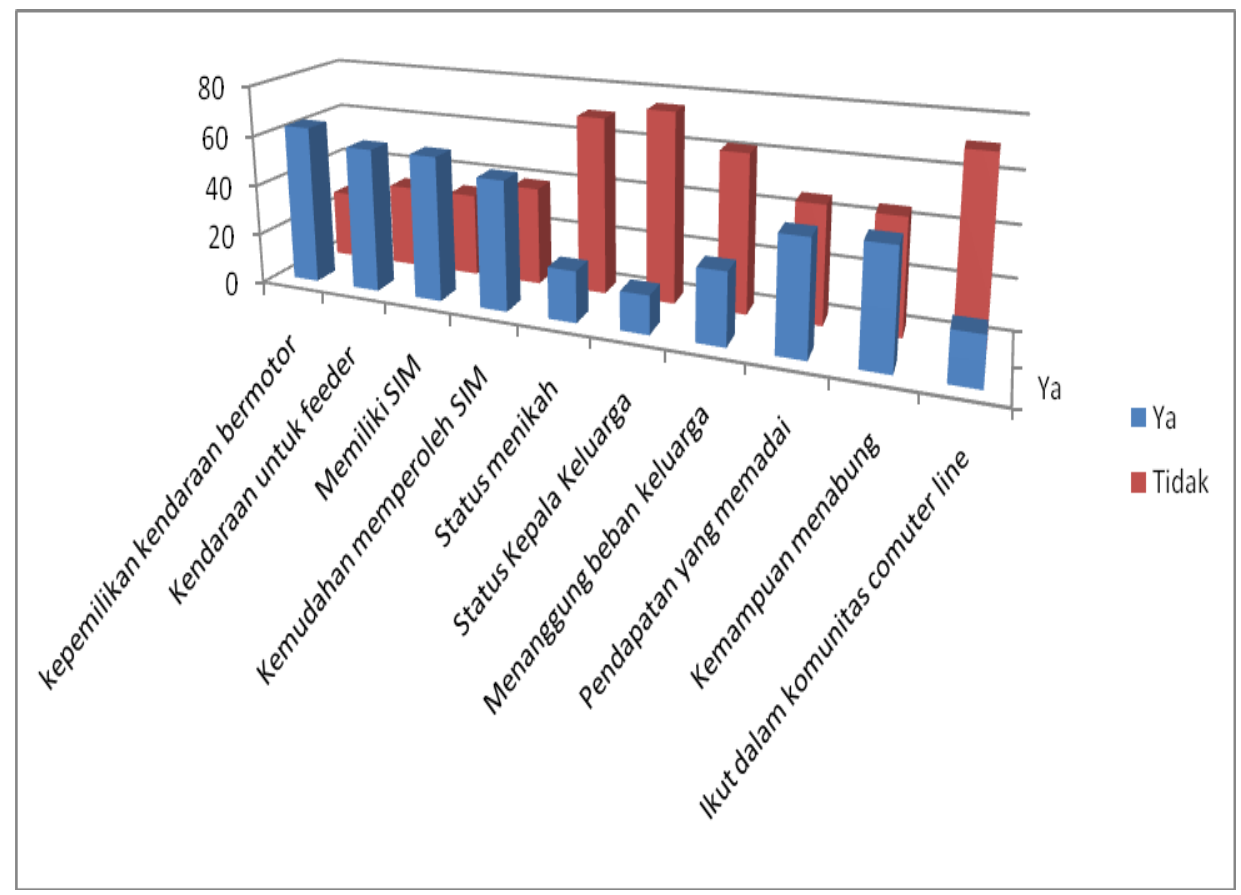

Gambar 1. Grafik Ciri Pengguna

Berdasarkan ciri pengguna, responden paling banyak non PNS, yaitu karyawan pada perusahaan-perusahaan, buruh, pedagang yang menggunakan comuterline sebagai pilihan dalam melakukan pergerakan untuk bekerjanya. Responden yang belum bekerja paling sedikit meliputi pelajar/mahasiswa atau berada pada usia produktif tetapi belum mendapatkan pekerjaan. Berdasarkan tingkat pendidikan responden paling banyak SMA, dikarenakan tingkat pendidikan inilah yang paling banyak dijumpai ketika penelitian berlangsung. Tingkat pendidikan ini dapat diterima sebagai tenaga kerja operator, meskipun ada tingkat perguruan tinggi sebagai jawaban paling banyak kedua.

Responden memiliki kendaraan bermotor baik roda dua dan empat. Kendaraan ini digunakan untuk melakukan pergerakan dari rumah sampai ke stasiun. Responden memilih kereta sebagai moda dikarenakan dapat diandalkan untuk melakukan pergerakan rutinitas. Meskipun memiliki kendaraan bermotor tetapi lebih memilih comuter line karena kemacetan yang terjadi jika menggunakan moda berbasis jalan raya. Mengutip yang dikemukakan ketua Dewan
Transportasi "di tahun 2010, kecepatan ratarata kendaraan bermotor $10 \mathrm{~km}$ per jam. Empat tahun setelahnya, kecepatan kendaraan semakin menurun sampai $5 \mathrm{~km}$ per jam'. Melihat ini responden lebih memilih comuter line sebagai pilihan dalam melakukan perjalanan.

Dari segi kelengkapan kendaraan bermotor responden memiliki SIM sebagai syarat utama dalam berkendara. Jarak yang dekat tidak mengurangi responden untuk melengkapi adminstrasi dalam berkendara. Kesadaran akan kepemilikan surat ijin ini sebagai salah satu usaha untuk tertib dalam lalu lintas. Cara memperoleh SIM ini juga menurut responden sangat mudah, yaitu dengan datang langsung ke Samsat atau melalui biro jasa yang ada. Responden tidak mengalami kesulitan untuk memperoleh maupun memperpanjang SIMnya.

Kendaraan bermotor yang digunakan responden sebagai feeder/pengumpan.. Distasiun-stasiun Depok, Tangerang, Bekasi dapat dijumpai parkiran kendaraan bermotor yang akan padat pada pagi hari dan sore hari. Parkiran ini ada yang disediakan pikak PT KAI maupun oleh warga yang memiliki lahan cukup disekitar stasiun. Parkiran ini menjadi rezeki 
sendiri bagi warga karena dengan mengandalkan tempat yang cukup dan tenaga pengatur dapat memperoleh keuntungan yang relatif sebagai alternatif memperoleh pendapatan

Rata-rata status perkawinan responden belum menikah, jika dilihat dari usia responden rata-rata 26,9 tahun, merupakan usia yang matang untuk melakukan perkawinan. Responden yang menjadi kepala keluarga tentunya sangat sesuai dengan status perkawinannya. Dari 20 responden yang melakukan perkawinan hanya 15 responden sebagai kepala keluarga, sisanya 5 responden kemungkinan pasangan/istri dari kepala keluarga. Responden ini tentunya akan menangung beban kelurga. Kepala rumah tangga bertanggung jawab terhadap roda ekonomi keluarga.

Berdasarkan pendapatan yang diperoleh responden menyatakan belum memadai kebutuhan, meskipun ukurannya sangat relatif. Responden menyatakan pendapatan yang diperoleh terutama bagi yang sudah menikah dan status kepala rumah tangga, pendapatan ini kurang dapat mencukupi kebutuhan. Mengingat biaya hidup yang tinggi bagi responden pendapatan yang kurang memadai inilah sehingga melakukan perjalanan dengan kereta api. Meskipun sangat relatif ukuran pemenuhan kebutuhan bagi tiap keluarga. Pilihan penggunaan kereta api comuterline dianggap cocok dengan berbagai pertimbangan. Meskipun ada responden yang memiliki pendapatan yang cukup dengan kepemilikan kendaraan roda empat, tetapi akan memilih kereta api comuterline karena dianggap lebih boros dan memerlukan waktu yang lebih lama. Pendapatan yang tidak memadai tentunya akan kesulitan untuk menabung

Responden sebagian besar tidak ikut dalam komunitas comuterline. Hanya sebagian kecil yang ikut dalam komunitas comuterline. Komuniatas ini dapat terbentuk karena frekuensi pertemuan yang intens dalam perjalanan, maupun ikut dalam anggota dalam dunia maya seperti twiter, facebook dan lain sebagainya. Sebagian besar responden masih adanya keengganan untuk terlibat dalam komunitas yang ada. Jika ingin memperoleh informasi, jadwal tentang perjalanana dapat ditanyakan langsung ke petugas.

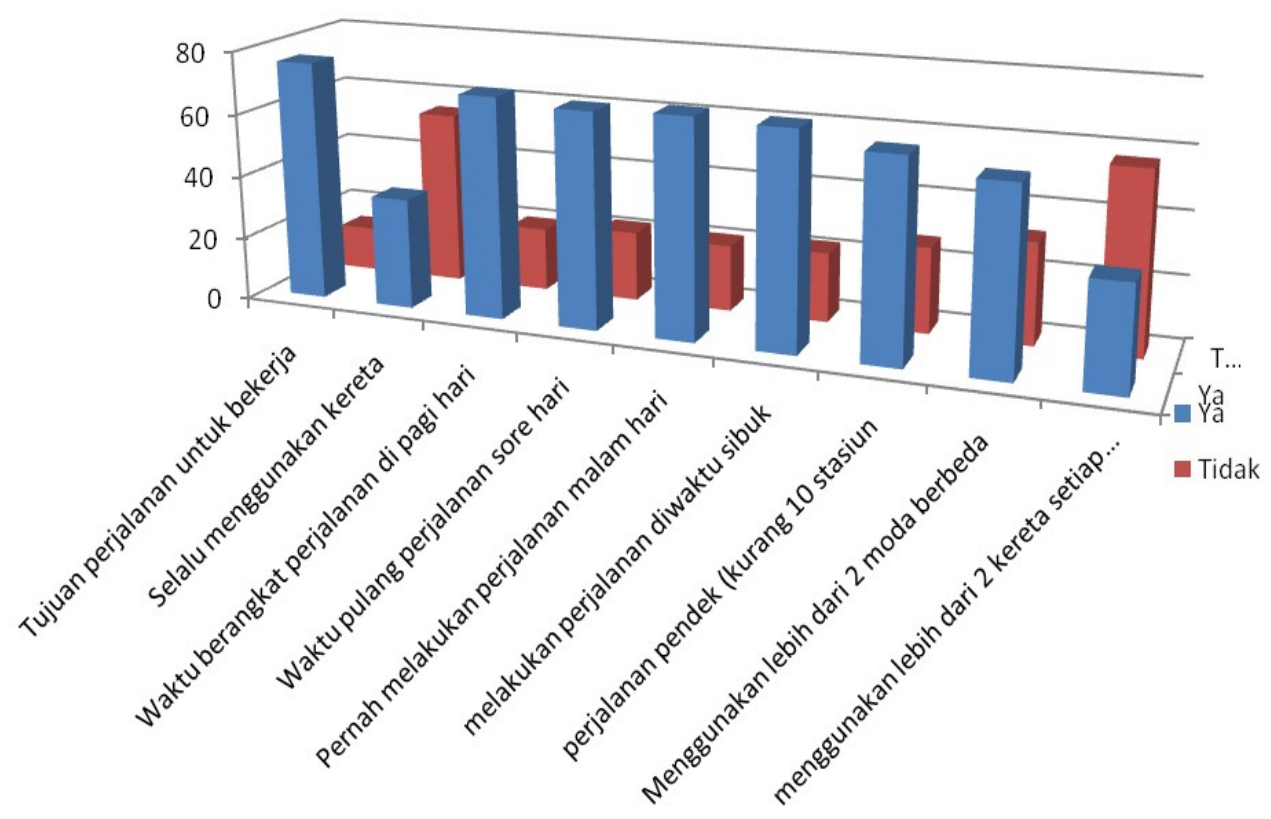

Gambar 2. Ciri pergerakan responden 
Berdasarkan ciri pergerakan sebagian besar tujuan perjalanan responden untuk tujuan bekerja. Responden melakukan perjalanan secara rutin dengan tujuan bekerja diwilayah Jakarta. Asal pergerakan dari Depok Tangerang, Bekasi, sebagai daerah origin, dibangkitkan perjalanan di Jakarta sebagai destination. Komutasi ini menjadi rutinitas harian. Responden memiliki tempat tinggal di daerah penyangga Jakarta, dan bekerja di Daerah Jakarta. Tujuan bekerja ini menjadikan terjadinya kepadatan penumpang pada hari kerja dan jam sibuk berangkat dan pulang kerja. Sebagain besar responden selalu menggunakan comuterline untuk melakukan perjalannya. Bagi tujuan responden lainnya tujuan perjalanan dilakukan untuk sekolah dan kegiatan sosial lainya.

Berdasarkan ciri fasilitas modanya, responden melakukan perjalanan berangkat pada pagi hari, pulang sore hari. Karena dilakukan secara bersama-sama maka terjadi kepadatan yang luar biasa pada jam sibuk. Jam sibuk comuterline pada pagi hari jam 06.0008.00 dan pada sore hari jam 16.00-18.00. Untuk menghindari pada jam sibuk ini responden akan berangkat setelah subuh sekitar jam 05.00 dan pulang setelah jam18.00, sehingga pada jam ini juga masih terlihat kepadatan pada tiap-tiap gerbong kereta. Mulai 14 Januari 2014 PT KCJ menambahkan jadwal perjalanan, sayangnya jadwal comuterline bukan pada jam sibuk kerja. Penambhan jadwal perajalanan ini untuk lintas Bogor-Depok sebanyak 8 perjalanan dan Bogor-Jatinegara 4 jadwal. Dengan tambahan tersebut total rute perjalanan comuterline di Jabodetabek perharinya menjadi 571

Rute yang tersedia Bogor-Jakarta, Bekasi Jakarta, Sepong-Jakarta, Tangerang Jakarta. Rute ini melewati beberapa stsiun, akan berhenti menaik turunkan distasiun. Meskipun tidak semua stasiun akan melayani penumpang comuterline seperti stasiun ancol, angke, gambir, tanjung priuk (tidak melayani), Cipinang, Grogol, Mampang, Kembangan, Tanah Tinggi (non aktif). Hasil penelitian menunjukan responden yang berasal dari Depok, Tangerang Bekasi melakukan perjalanan pendek yaitu kurang dari 10 stasiun. Jarak yang pendek ini dilakukan untuk menghemat waktu yang ditempuh dibandingkan dengan menggunakan kendaraan pribadi/umum.

Responden melanjutkan perjalanan dengan moda lain yang ada, stasiun yang ada sudah terintegrasi dengan angkutan umum seperti metromini, transjakarta, bajaj maupun ojek sehingga responden akan sangat mudah melajutkan perjalanannya. Responden akan melakukan perpindahan dari satu moda ke moda lainnya dari rumah sampai ketempat kerja, tetapi dengan waktu tempuh yang tidak lama. Responden lebih memilih mengunakan moda transportasi yang berbeda untuk menghindari kemacetan yang lama terutama pada jalan raya yang menuju ke Jakarta yang akan padat pada pagi dan sore hari.

Responden tidak melakukan perpindahan dari satu kereta kereta lain, karena akan merepotkan, sebagian besar responden hanya melakukan satu kali kereta untuk melakukan perjalanan kemudian disambung dengan moda lain. Beberapa stasiun yang digunakan untuk transit yaitu Manggarai, Jatinegara, dan Tanah Abang. Meskipun ada responden yang malakukan transit distasiun tersebut tetapi jumlahnya tidak sebanyak yang melakukan 1 kali perjalanan dengan menggunakan kereta. Bagi yang belum terbiasa akan terjadi kesulitan ketika harus berpindah kereta. Harus dicermati pada peron berapa kereta yang akan dinaiki, sehingga akan merepotkan responden dalam pemindahannya. 


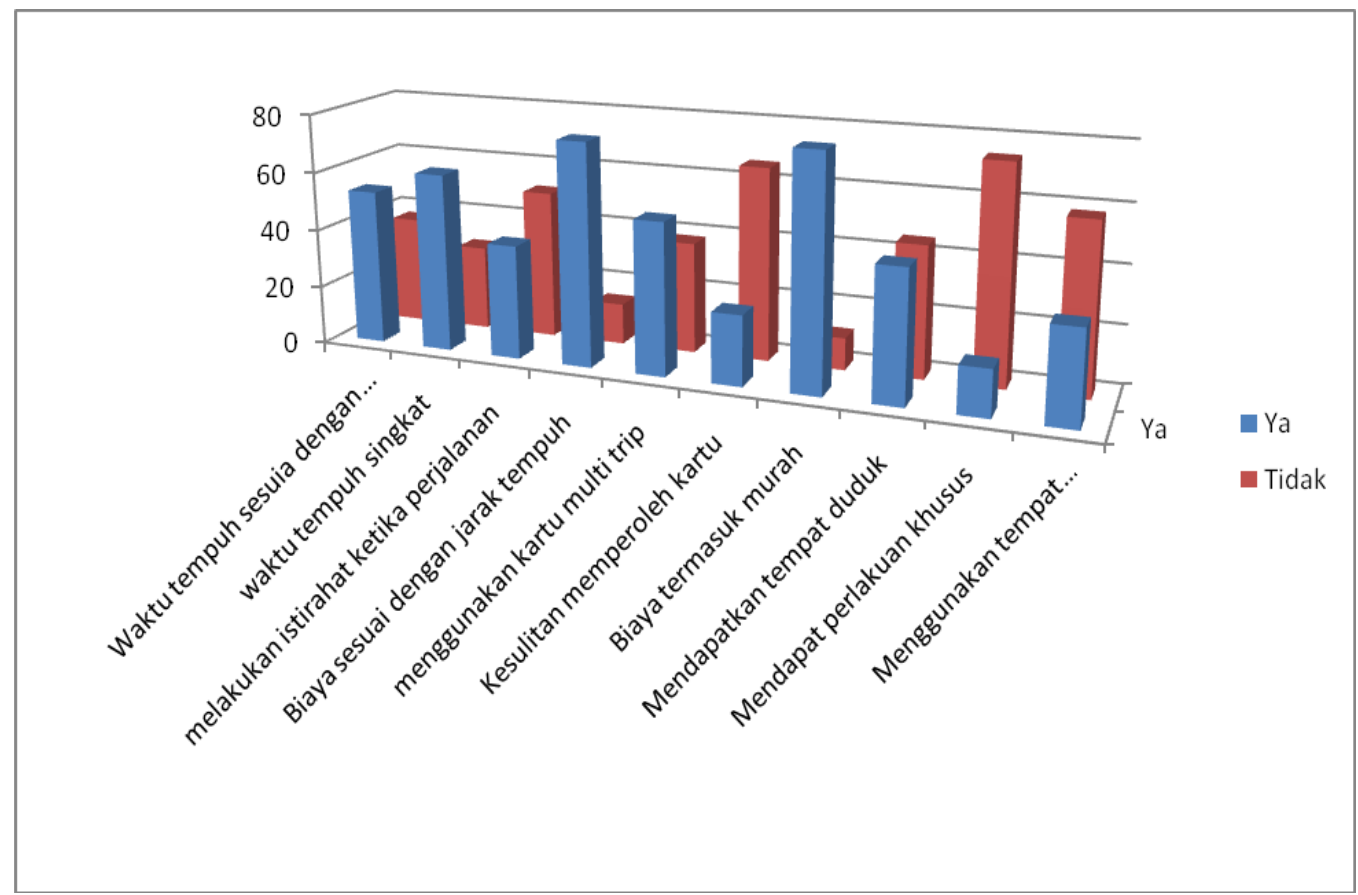

Gambar 3. Ciri pengguna waktu tempuh yang diperlukan responden

Berdasarkan ciri pengguna waktu tempuh yang diperlukan responden untuk melakukan setiap perjalanan sudah sesuai dengan keinginannya. Waktu tempuh Jakarta-Bekasi kurang lebih 48 menit dengan melewati 14 stasiun . Waktu tempuh JatinegaraBogor/Depok Kurang lebih 1 jam 38 menit dengan melewati 28 stasiun Waktu Tempuh Bekasi-Depok/Bogor kurang lebih 1 jam 17 menit melewati 23 stasiun. Waktu tempuh Maja-Tanah Abang kurang lebih 1jam 34 menit melewati 16 stasiun. Waktu tempuh DuriTangerang kurang lebih 36 menit melewati 7 Stasiun. Bagi responden waktu tempuh termasuk singkat dibandingkan dengan moda berbasis jalan raya. Menurut Ketua Dewan transportasi, keceapatan rata-rata kendaraan bermotor di Jakarta $5 \mathrm{~km} / \mathrm{Jam}$. Sehingga responden memilih moda tranportasi comuterline dibandingkan yang lainnya. Dengan membagi waktu tempuh dan stasiun yang dilewati maka perjalan tiap stasiun berkisar 4-5 menit. Untuk perjalanan pendek (10 stasiun) dibutuhkan waktu 50 menit. Waktu yang lainnya yang dihabiskan untuk membeli tiket, mengantri, menunggu kedatangan kereta dan menunggu keberangkatan kereta.
Dengan waktu tempuh yang kurang dari 1 jam responden tidak istirahat/tidur ketika dalam kereta. Faktor karena kondisi yang penuh sesak pada jam sibuk, tidak adanya ruang/tempat duduk, keaadan yang penuh sesak sehingga responden tidak dapat melakukan istirahat. Aktivitas yang dilakukan baisanya memainkan/mendengarkan musik atau lainnya dari gadget, ngobrol, atau diam saja. Responden tidak banyak melakukan aktivitas dengan kondisi yang penuh.

Biaya yang dikeluarkan responden termasuk murah, untuk jarak yang terjauh diperlukan biaya RP 7.000 , dengan biaya yang cukup murah menempuh kuarang lebih 30 stasiun dengan waktu 90 menit. Biaya ini bila dibandingkan dengan moda berbasis jalan raya tidak akan sesuai karena akan terjadi waktu tempuh yang lebih panjang dengan jarak yang sama. Biaya untuk perjalanan pendek (10 stasiun) sebanyak Rp 3.000 termasuk biaya yang murah. Bandingkan dengan tarif angkutan dan waktu tempuh yang diperlukan. Responden memilih comuterline dengan alasan biaya rasional dengan waktu tempuh, meskipun tidak nyaman di jam sibuk. 
Responden lebih banyak menggunakan kartu multi trip daripada single trip, karena mengangap dengan menggunakan multi trip tidak perlu antri setiap kali akan melakukan perjalanan untuk membeli tiket. Ketika saldo mendekati habis baru mengisi sesuai dengan keinginan. Jika menggunakan kartu single trip harus mengantri ketika mau membeli tiket, dengan jaminan 5.000 kartu single trip dapat diuangkan kembali ketika keluar dari stasiun akhir tujuan perjalanan. Untuk memperoleh kartu multi trip juga tidak sulit hanya dengan membeli kartu seharga Rp 50.000 akan terisi saldo Rp 20.000 dan saldo dapat diisi kembali jika mendekati limit. Bagi responden pekerja adanya waktu yang dapat di hemat dari pengunaan multi trip ini.

Separuh responden tidak dapat tempat duduk. Apabila responden naik dari kereta awal berangkatan/kereta balik kemungkinan akan mendapatkan tempat duduk. Kereta balik dapat di temukan pada stasiun Bogor Depok, Bekasi, Serpong Bagi wanita dapat menggunakan gerbong kereta khusus wanita di gerbong awal dan terakhir. Atau juga dapat menggunakan tempat duduk prioritas yang berada di setiap gerbong. Tempat duduk prioritas digunakan untuk wanita hamil, manula, tuna daksa. Apabila disekitar tidak ada dengan kriteria tersebut siapapun boleh duduk. Ketika jam sibuk tempat duduk prioritas terkadang kurang tepat karena kondisi yang padat sehingga siapapun akan duduk ditempat ini.

\section{KESIMPULAN}

Karakteritik responden umur paling muda 16 tahun dan paling tua 50 tahun dengan ratarata 26,9 tahun. Berdasarkan tingkat pendidikan responden paling banyak SMA.

Berdasarkan ciri pengguna responden memiliki kendaraan bermotor baik roda dua dan empat. Dari segi kelengkapan kendaraan bermotor responden memiliki SIM Kendaraan bermotor yang digunakan responden sebagai feeder/pengumpan. Rata-rata status perkawinan responden belum menikah. Bagi yang sudah menikah pendapatan yang diperoleh responden menyatakan belum memadai kebutuhan. Pendapatan yang tidak memadai tentunya akan kesulitan untuk menabung. Responden sebagian besar tidak ikut dalam komunitas comuter line.

Berdasarkan ciri pergerakan sebagian besar tujuan perjalanan responden untuk tujuan bekerja. Sisanya untuk kegiatan sosial, rekreasi dan belajar

Berdasarkan ciri fasilitas modanya, responden melakukan perjalanan berangkat pada pagi hari, pulang sore hari. Jam sibuk komuter line pada pagi hari jam 06.00-08.00 dan pada sore hari jam 16.00-18.00. Jarak yang pendek ini dilakukan untuk menghemat waktu yang ditempuh dibandingkan dengan menggunakan kendaraan pribadi/umum. Responden melanjutkan perjalanan dengan moda lain yang ada, stasiun yang ada sudah terintegrsi dengan angkutan umum seperti metromini, transjakarta, bajaj maupun ojek. Responden tidak melakukan perpindahan dari satu kereta kereta lain.

Waktu tempuh yang diperlukan responden untuk melakukan setiap perjalanan sudah sesuai dengan keinginannya. Untuk perjalanan pendek (10 stasiun) dibutuhkan waktu 50 menit. Responden tidak istirahat/tidur ketika dalam kereta. Biaya untuk perjalanan pendek (10 stasiun) sejumlah Rp 3.000 termasuk biaya yang murah. Responden lebih banyak menggunakan kartu multi trip daripada single trip. Separuh responden tidak dapat tempat duduk, responden yang duduk dapat digerbong wanita atau tempat duduk prioritas.

\section{DAFTAR PUSTAKA}

Badan pusat Statistik (BPS): Jakarta Dalam

Angka, 2000

Bintarto, dan P. Hadisumarno, 1991, Metode

Analisa Geografi, Jakarta : LP3ES

Chris Manning, Efendi T.N., 1996, Urbanisasi,

Penganguran, dan Sektor Informal di Kota,

Yayasan Obor Indonesia, Jakarta

DLLAJR DKI Jakarta, 1983, Travel Time and

Traficc Volume.

Bis Kota
Lintas Angkutan Jakarta Raya


Hoobs, F.D., 1995, Perencanaan dan Teknik Lalu Lintas di Jalan Raya, Yogyakarta : Gajah Mada university Pres.

Masket, Djunaedi, 1988, Pengetahuan Praktis Berlalu Lintas di Jalan Raya, Bandung : Mitra Grafika.

Moenodji, 2000, Transportasi Perkotaan dan Angkutan Umum, Yogyakarta: DLLAJ
Morlok, E.K., 1995, Pengantar Teknik dan Perencanaan Transportasi, Penerbit Erlangga, Jakarta

Muchtarudin, S., 1990, Beberapa Masalah Ekonomi dan Manajemen Pengangkutan, LPFEUI, Jakarta

Tamin, Z. Ofyar, 2000, Perencanaan dan Pemodelan Transportasi, Bandung : ITB. 